THE TRUTH-COMMISSION:

\title{
PUBLIC DEBATE AND THE ROLE OF RELIGIOUS BODIES (AFRIKANER/DRC)
}

Antje Krog

Poet, writer and journalist

Cape Town

\begin{abstract}
Unlike academics it is not my task to repeat what I have written. So I am deliberately moving away from the Truth Commission angle in "Country of my Skull" to use this opportunity to try and determine what kind of religious spaces are needed in the country, more especially in the rural areas and explore whether the churches and especially the Afrikaans Churches are or can be providing these spaces. In conclusion I would like us to consider whether South Africa can afford to be without such spaces.
\end{abstract}

\section{Spaces provided by the church during apartheid in the rural areas}

Let me take you to a town which was a town like many others during the seventies and eighties. The Catholic clerics there lived in a house on a small hill overlooking the town. Although they were somewhat isolated by the town, there was a general believe that the enormous masthead in front of their house enabled them to "speak directly to Russia". The members of the Catholic church might have been white but the town regarded them as Portugese and Greek café owners or Libanese business people and farmers. The English churches were a strange mix: the Methodist church provided space for the more common English and the Anglican for the more grand English. Why there was a Presbyterian church, few understood and even less had cared. But it was assumed that a lot of the people in these churches were as racist as the Afrikaner, but that they somehow had managed to sound "open" while they were in fact "closed". Although their national leaders were black, although their halls and centres in the townships were used for political activities, although their pastors and fathers often molested over the colour line, their services in town were exclusively white. The Afrikaner churches on the other hand were what we would call today: Proudly White.

During the eighties I was teaching at the local coloured high school in one of these platteland towns. One of my jobs was to accompany the school choir on the piano - with our first attempt we came third at the national competition in Cape Town. We suddenly realised we could actually win and threw ourselves heart and soul into the preparations. We collected special songs, had them arranged by the best the Free State could offer catering for problems with halftones and sevenths and decided to put a special long weekend aside to take the children out of their surroundings so that they could start doing voice and pronunciation exercises and get trained to produce a consistent sound. The church I belonged to had a centre at a big dam that most local schools used for a variety of activities. The place was however more infamous as the love nest of the scandalous affairs of at least two ministers and one elder. I applied for permission to use this facility, it was turned down. 
The minister heading the committee explained to me that some members were unhappy about it and out of fear for losing more members to the recently established APK church, permission was refused. I resigned from the church.

Within two months our own congregation refused permission for a black choir to sing on Mission Sunday. Thereafter my husband, who was a diaken at that stage, also resigned. We then became members of the NG Sendingkerk in the coloured township where the dominee preached in Afrikaans and the congregation sang in Sesotho.

A lot of our friends made similar choices - not because we were activists or rebels, but because the white churches no longer made it possible for people to live their ordinary daily lives according to their consciences, the churches made it difficult to do the right thing in a country haunted by injustice.

For me and my family it felt as if we have become Christians for the very first time. As if our lives and our religion, our thoughts and our believes could function for the first time as a unit. As if what you have believed and where you lived made sense. Our church was part of the town, part of the country, part of the spectrum of God's children. On Sundays we were no longer driving even more inward to the complacent white heart of our town, but driving outward towards the plasticbag-blown ash-coloured township to sit in a cheap hall shoulder to shoulder with people who needed to garner enough strength during the following few hours to enable them to make it through the coming week. It was difficult, but it also brought a keen sense of no longer escaping the consequences of our believe. We sang in languages we did not understand, listened to rhythms we never knew. Where simple messages, lengthy sermons, repetition used to irritate the life out of me, in this simple church you could literally see how it sustained people, how it changed their harrowing lives into some quiet closeness with God.

Everything was there: poverty and the riches of talking and laughing, hunger and the fulfilment of peace, oppression and liberation, injustice and complete belonging. Myself and my family have been accepted in that community like nowhere before and nowhere afterwards.

The more we got involved with the church activities, the more we realised that the life of a country has a profound influence on the life of a church. We realised how poverty tests moral values, how hunger affects one's view of God, we came to appreciate not the fact that Christ had died on the cross, but that he lived among the poor, that he fed them with both food and values. I became strongly dismissive of Christ dying for my sins, what bound me to him was that he lived in complete unity with his universe. He cared completely and was one with the poor and the water and the air.

Before dawn on Easter Sunday the congregation always gathered at the run down cemetery from where the dominee would lead us: threading our way with mournful hymns among the fallen wooden crosses and anonymous mounds to an open empty grave. There, looking into the empty grave the dominee would shout: he has risen and the hymns would change into a triumphant jubilations resounding over the still sleeping town. Jesus has risen from this dusty grave where the first autumn chill is already in the air. We sang of hope and joy and love and caring.

The service on Sundays had to start early to lure some away from drinking and abuse, it had to last long because some homes were overcrowded and threatening. The fetes were a tour de force of cents, Christmas times a breathtaking experience of joy within hardly any material expectations at all. We as a family learned how to live outside ourself, learned to share, to accept, to fit in, to give, to live within the real relationships of this country - 
although in a way still from the outside, yet at the same time more inside this country than ever before.

To crown it all: when there was a political march, our dominee would walk in the front row together with the other activists, while the diakens from our erstwhile church were lining the streets with guns and dogs, hatred and fear.

Let me interrupt the account at this point. Why am I telling you this? Because this had been the experience of quite a number of Afrikaners during the eighties - they found themselves in a country where neither the politics nor their jobs nor their suburbs, nor the schools nor the churches made it possible for them to live their lives dictated by their values. I think not much has changed today.

But let me continue. Those men lining the streets with guns and dogs were seen again this time applying for amnesty before the TRC. As they testified, it became clear: they were to the man faithful office bearers in their churches. But there they were sitting, with their families, kicked out of their suburbs, unrecognised and unsupported by their churches and rejected by their political party as "bad apples". Was there debates in the church about the extend of accountability, of collective guilt, of shame? Was there discussions about what forgiveness entails, reconciliation? If indeed it happened, the country heard very little of it in public. The language of accountability and forgiveness was not formed in such a way that church members could learn to take it on their tongues.

Why not? If the church couldn't provide a space for all of God's children, why could it also not find space for those who protected the exclusivity of some of his children. Those reborn Christians who have privatised the vertical line to God with such fever that it became one dimensional, are anyway serving God in their selfindulgent congregations outside the church. So for whom does the church then provide a space today?

\section{What are the churches giving space to?}

According to the Afrikaans letter columns the church is providing space for two things: to deal with The Big Doubt and to deal with: Our Role in the Past. Both praiseworthy exercises no doubt. Yet at the same time the church is being consumed by problems of survival. In the cities, towns and villages. Many of the congregations are literally living from month to month. Members are being put under pressure to give enough so that dominees can stay on, so that the church need not be sold, so that amalgamation can be postponed. The church therefore dare not give offence for fear of losing that extra rands per month that could keep the wolf from the door of the dominee and his family.

Now the church bends over backwards, and bends sideways, crawls on its knees. The carpets are rolled out for those who give their thank-offering. To keep the youth and the charismatically inclined the church changes its style, language and rhythm. It forges relationships with businesses, with other congregations, it sells its manses and make do with one dominee. In the congregations where things are a bit better off, mission-fever had been replaced by charity-fever. Wonderful work is being done for the poor and the elderly, the unemployed and illiterate. And for that one takes off one's hat. The church can pull its middle-class weight.

But is that the task of the church? Charity and the cultivation of paid up souls? Is the only debate really whether Jesus is the son of God and his mother a virgin and how much the creation forms part of evolution? Is our only expectation that the church should say what was wrong and unfair in the past? About now it has no viewpoint because it has to survive? Is the only relationship we see for ourselves with our fellow African Christians that of charity? But is that the sum total of what the church should be? 
I have the deepest respect for those who fight for the Belhar Belydenis and those trying to sort out the problems surrounding unity among the churches, die Eenwording. But is this where the focus should be? Old fights, property allocations, belated confessions while the animosity and estrangement grow daily among Christians in this country.

So it is precisely at this point that one is tempted to wipe the church off the table as being totally non-important, non-influential, non-powerful and non-effective. One is tempted to ask whether the church has ever changed, meant or sustained anything worth while in this country except selfish transgressions and indulgence in differences? But one should not say it, because the more important question is of course: can this country afford to wipe the Afrikaner churches from the table, can this country survive without the church and more specifically the Afrikaans Reformed churches?

Before answering that, let me take you back to the villages clustering around the church spirals, scattered through the rural areas. These are the places confronted with the brutal face of transformation. This is the real coal face. On national level we have transformed. The leaders are black, we accepted that and not much has changed in our lives; on provincial level we have transformed, the rulers are black, we accepted that and not much has changed in our lives. The same in cities. But in the rural areas it is a different story. Here the resources are scarce and they belong only to those who refuse to give up. In the schools, shops, business areas, suburbs, townships, municipalities, the fight is hard and harsh: the needs are vast, the resources few. It is from these towns where racism makes the headlines, not because the people are more racist, but because there are less protection and fewer buffers. Survival has become the only value, branding each into racial stereotypes an important tool.

No wonder then that $56.4 \%$ of blacks, more than half of all blacks, can say that they do not know of a white person whom they could call a friend. More than a third of all whites can not think of a single black, including the woman who works in the house, whom they could call a friend. Yet most South Africans are Christians.

But how can we become friends if more than $80.7 \%$ of black people have never shared a single meal with a white person, (let me emphasise: not receiving food from whites, but sharing food with whites), while nearly half of the white population, $45 \%$, has never shared a meal with a black person. A more upsetting statistic can be deduced from this: $14 \%$ of black people then do have a white friend but has never shared a meal with him or her. (Statistics provided by the Institute for Justice and Reconciliation)

Where do we think we are going with these kind of statistics. How does the church explain these statistics among its Christians?

Isn't it so that one expects the church to be the one place where there is sharing? Where there is no competition for resources, because the church provides space to all of God's children? Where they can meet and share and be strengthened and comforted for their our daily struggles? Why isn't the church pre-eminently the place where Christians meet and care for each other knowing that the grace of God is good and enough? Why is there not a massive link up of churches across suburbian borders, holding communion together, Good Friday, why do we not sing each others hymns, have we no translation services during sermons? Where are the fetes planned by several congregations across borders, where is the Christmas concert with black angels, white shepherds and a coloured baby Jesus?

Then we can close up shop, one dominee said to me. My counter question is: can this country afford that ten years down the line of democracy more than $80 \%$ black people has never shared a piece of bread with a white person? And why would such a black person one day repudiate a political leader who says: you have nothing because of the whites. Why 
would $80 \%$ of black people ever choose the side of whites, of people whom they know nothing about?

The first election was so peaceful partly because white and black, despite the apartheid laws, more than often managed to establish some kind of solid relationships with each other. Within the forced unequal framework people knew and trusted one another to a larger extend than anybody suspected. This has changed. The framework has changed. We have to build a new relationship. As equals we have to build it. Not with charity or as missionaries, but as equals. As Gods children we have to get to know each other from scratch, accept each other and love each other. The politics in this country does not provide that space, nor the workingplace, nor suburbs, because they are all contested spaces of power and access to resources. Except the church. It is the only place where people are people because God made them and there is mercy and blessing, forgiveness and love enough to fill the whole world.

I do not have to spell it out: there need to be enough black people to empirically say: I know whites, I live with them, I pray with them, they are people like me - we all try to keep this farm, this town, this country on its feet. Even more importantly - there need to be more Christians who can say empirically: whites or blacks are not more selfish. more filled with hatred, more revengeful, more incompetent, more caring that the rest of us - we have become each other, we have been formed by each other and this is how God cares for us.

And this is not a political request, but a fundamental question about the innermost fibre of Christianity. Rather like asking the church: why do you use only one leg. If you release your hand, you will be able to walk like you have been created to walk the earth.

In conclusion, if the church could provide the space for fellow Christians to meet one another and live with one another, it would send shock waves through the calcified moral artery system of this country. It would enable a country currently living off a set of artificial machines, to wake up with a transplanted heart which beats warm and strong with the mercy of God for all its people. 